\title{
PENGARUH KARAKTERISTIK PEKERJAAN DAN EFIKASI DIRI TERHADAP KETERIKATAN KERJA DAN IMPLIKASINYA TERHADAP KEPUASAN KERJA
}

\section{Fiona Citrayani, Tetra Hidayati, Saida Zainurossalamia}

Magister Manajemen Fakultas Ekonomi dan Bisnis Universitas Mulawarman, Indonesia

Email: ficytra26@gmail.com, hidayati.tetra@yahoo.com,

saida.zainurossalamia.za@feb.unmul.ac.id

\begin{abstract}
Abstrak
Artikel ini membahas pengaruh karakteristik pekerjaan dan efikasi diri terhadap kepuasan kerja dengan keterikatan kerja sebagai variabel mediasi. Responden yang diteliti adalah 60 Pegawai Negeri Sipil yang ada di Kecamatan Samarinda Ilir. Pengumpulan data dilakukan dengan menggunakan kuesioner. Metode analisis yang digunakan adalah Structural Equation Model (SEM) dengan pendekatan Partial Least Square (PLS). Analisis data melalui PLS dilakukan melalui dua tahap, yaitu: pertama, menilai outer model atau model pengukuran. Kedua, menilai Inner model atau model struktural. Hasil penelitian menunjukkan bahwa karakteristik pekerjaan berpengaruh positif dan signifikan terhadap keterikatan kerja, efikasi diri berpengaruh positif dan signifikan terhadap keterikatan kerja, karakteristik pekerjaan berpengaruh positif dan signifikan terhadap kepuasan kerja, efikasi diri berpengaruh positif dan tidak signifikan terhadap kepuasan kerja, keterikatan kerja berpengaruh positif dan signifikan terhadap kepuasan kerja, karakteristik pekerjaan berpengaruh positif dan signifikan terhadap keterikatan kerja melalui keterikatan kerja, dan efikasi diri berpengaruh positif dan signifikan terhadap kepuasan kerja melalui keterikatan kerja.
\end{abstract}

Kata Kunci: karakteristik pekerjaan; efikasi diri; keterikatan kerja; kepuasan kerja

\section{Abstract}

This article discusses the influence of job characteristics and self-efficacy on job satisfaction with work engagement as a mediating variable-respondents who researched were 60 Civil Servants in Samarinda Ilir District and collected data using a questionnaire. The analytical method used is the Structural Equation Model (SEM) with the Partial Least Square (PLS) approach. Data analysis through PLS uses two stages: first, assessing the outer or measurement models. Second, consider the inner model or structural model. The results of the research showed that job characteristics had a positive and significant effect on work engagement, selfefficacy had a positive and significant effect on work engagement, job characteristics had a positive and significant impact on job satisfaction, selfefficacy had a positive and insignificant effect on job satisfaction, work engagement had a positive and significant effect on job satisfaction, job characteristics had a positive and significant impact on job satisfaction through work engagement, self-

$\begin{array}{ll}\text { How to cite: } & \text { Fiona Citrayani, Tetra Hidayati, Saida Zainurossalamia. (2022) Pengaruh Karakteristik Pekerjaan dan Efikasi } \\ & \begin{array}{l}\text { Diri Terhadap Keterikatan Kerja dan Implikasinya Terhadap Kepuasan Kerja. Syntax Literate: Jurnal Ilmiah } \\ \text { Indonesia, 7(1). http://dx.doi.org/10.36418/ Syntax-Literate.v7i1.6046 }\end{array} \\ \text { E-ISSN: } & \text { 2548-1398 } \\ \text { Published by: } & \text { Ridwan Institute }\end{array}$


Fiona Citrayani, Tetra Hidayati, Saida Zainurossalamia

efficacy had a positive and significant impact on job satisfaction through work engagement.

Keywords: job characteristic; self efficacy; work engagement; job satisfaction

Received: 2021-12-20; Accepted: 2022-01-05; Published: 2022-01-15

\section{Pendahuluan}

Organisasi yang mampu berkembang salah satu faktor utamanya adalah Sumber Daya Manusia (SDM) yang berada di dalamnya. Pengembangan organisasi dan kinerja organisasi akan sangat ditunjang oleh pengelolaan SDM dengan cara meningkatkan kinerjanya (Diamantidis \& Chatzoglou, 2019). Tuntutan untuk meningkatkan kinerja, khususnya dalam organisasi pemerintahan yang bergerak di sektor layanan publik hampir selalu menuntut keberadaan SDM yang handal dan berkinerja maksimal, sehingga dengan kinerja yang maksimal maka kepentingan organisasi dapat terpenuhi (Mappamiring, Akob, \& Putra, 2020). Dalam konteks organisasi, SDM adalah sumber daya organisasi yang paling penting (Turner \& Hulme, 1997). Pentingnya SDM dalam organisasi ini kemudian sejalan dengan pengelolaan SDM guna memaksimalkan keberadaan SDM bagi eksistensi, pengembangan, dan kemajuan dari sebuah organisasi.

Salah satu faktor penting dalam pengelolaan SDM adalah kepuasan kerja. Kepuasan kerja dapat menimbulkan pengaruh positif dan negatif dalam hal kinerja pegawai (Colquitt, Lepine, \& Wesson, 2014). Pegawai yang tidak puas dengan pekerjaannya sangat dimungkinkan memiliki sikap negatif terhadap pekerjaan, seperti meningkatnya absensi, menimbulkan turnover, stres, dan menurunkan kinerja pegawai. Dalam perspektif lain, terdapat berbagai konsekuensi positif yang ditimbulkan oleh kepuasan kerja. Konsekuensi tersebut berupa sikap positif dari pegawai, seperti peningkatan motivasi, keterikatan kerja, munculnya komitmen organisasi, munculnya organizational citizenship behavior, dan peningkatan kinerja pegawai (Kreitner, R. And Kinicki, 2013). Kinerja pegawai dan kepuasan kerja lebih mengarah pada sesuatu yang bersifat emosional karena dua hal ini memiliki keterkaitan dengan apa yang mampu diberikan, kontribusi, hingga kemampuan pegawai dalam bekerja (Narcisse \& Harcourt, 2008); (Robbins, S. P. And Judge, 2015). Kepuasan kerja yang tinggi dari pegawai biasanya selaras dengan kinerja pegawai yang tinggi. Oleh karena itu, penting untuk melihat bagaimana kepuasan kerja dalam organisasi pemerintahan yang bergerak dalam sektor layanan publik.

Kajian penelitian yang memiliki keterkaitan maupun hal-hal yang mempengaruhi kepuasan kerja akan selalu bersifat aktual dan dinamis, seperti karakteristik pekerjaan yang berpengaruh positif dan signifikan terhadap kepuasan kerja (Rai \& Maheshwari, 2020) maupun yang tidak signifikan (Fauzan, 2020), serta efikasi diri yang berpengaruh positif dan signifikan terhadap kepuasan kerja (Mokhtar, Maouloud, Omowunmi, \& Nordin, 2021) maupun yang tidak signifikan (Chegini, Janati, Asghari-Jafarabadi, \& Khosravizadeh, 2019). Kepuasan kerja juga bisa muncul sebagai hasil akhir dari keterikatan kerja (Saks, 2019). Keterikatan kerja dapat dipengaruhi secara positif dan 
signifikan oleh karakteristik pekerjaan (Prameswari, 2019); (Sulin, 2018); (Sulistyo \& Suhartini, 2019) maupun secara tidak signifikan (Saragih \& Margaretha, 2013). Selain itu, efikasi diri juga terbukti dapat mempengaruhi keterikatan kerja secara positif dan signifikan (Yu, Ariza-Montes, Giorgi, Lee, \& Han, 2020); (Al-Hamdan \& Bani Issa, 2021); (Mejia et al., 2021). Namun dari riset-riset yang telah dilakukan sebelumnya, belum ada yang membahas secara khusus bagaimana karakteristik pekerjaan dan efikasi diri mempengaruhi keterikatan kerja dan implikasinya terhadap kepuasan kerja.

Artikel ini ingin menjembatani ruang kosong dalam kajian riset tersebut, khususnya pada lingkup organisasi publik berbentuk kecamatan yang tugas utamanya adalah memberikan layanan publik secara langsung kepada masyarakat, yaitu di Kecamatan Samarinda Ilir. Selain menjembatani ruang kosong tersebut, riset ini juga didasarkan pada observasi langsung di lapangan yang menunjukkan masih adanya permasalahan ketidakpuasan pegawai terhadap pekerjaannya, yang disebabkan belum optimalnya pelaksanaan rotasi atau mutasi antar pegawai, pelaksanaan promosi yang tidak sesuai dengan keahlian atau kemampuan yang dimiliki oleh pegawai, serta komunikasi pegawai dengan rekan kerja yang belum maksimal karena pegawai cenderung memilih bekerja sendiri untuk menyelesaikan tugas terutama yang membutuhkan kerjasama tim. Permasalahan lain terkait dengan keterikatan kerja yaitu rendahnya disiplin kerja pegawai dengan masih ditemukannya pegawai yang absen dan tidak patuh jam kerja serta kurang fokus dalam penyelesaian pekerjaan. Sementara itu, dari sisi efikasi diri, permasalahan yang muncul adalah kurangnya kepercayaan diri pegawai dalam mengatasi persoalan kerja. Sedangkan dari sisi karakteristik pekerjaan, pegawai kurang bertanggung jawab atas pekerjaan yang diberikan karena kurang memiliki kebebasan untuk menentukan prosedur dalam menyelesaikan pekerjaannya.

Kepuasan kerja selalu mencerminkan bagaimana seseorang menyukai pekerjaannya. Kepuasan kerja dapat dibagi menjadi lima dimensi, yaitu kepuasan terhadap gaji, promosi, atasan, rekan kerja dan pekerjaan (Smith, 1969). Kepuasan kerja juga dapat dipengaruhi oleh upah, pekerjaan, promosi, penyelia dan rekan kerja (Robbins S.P., Judge T.A., 2015). Sementara itu terdapat lima model penyebab kepuasan kerja, yaitu need fulfillment, dicrepanciest, value attainment, equity, dan dispostional/genetic component (Kreitner, R. And Kinicki, 2013). Kepuasan kerja memiliki banyak variabel yang dapat mempengaruhi implikasinya seperti keterikatan kerja, karakteritik pekerjaan, dan efikasi diri. Karakteristik pekerjaan adalah dimensi inti dari suatu pekerjaan yang diberikan kepada pegawai. Indikator karakteristik pekerjaan terbagi menjadi lima, yaitu skill variety (variasi keterampilan), task identity (identitas tugas), task significance (signifikansi tugas), autonomy (otonomi), dan feedback (umpan balik) (Hackman \& Oldham, 1976). Efikasi diri adalah keyakinan atau kepercayaan yang dimiliki pegawai mengenai kemampuan dirinya untuk mengorganisasi, melakukan suatu tugas, mencapai suatu tujuan, menghasilkan sesuatu, dan melakukan tindakan untuk menunjukkan keterampilan tertentu (Kreitner, R. And Kinicki, 2013); (Robbins S.P., Judge T.A., 2015). Indikator efikasi diri terdiri dari level (tingkatan), generality (generalitas), dan strength (kekuatan) (Lightsey, 1999). 
Sementara itu, keterikatan kerja adalah sikap positif yang ada pada diri pegawai terhadap pekerjaannya. Indikator yang digunakan dalam penelitian ini mengadopsi indikator keterikatan kerja yang terdiri dari vigor (semangat), dedication (dedikasi), dan absorption (penyerapan) (Schaufeli, Salanova, González-Romá, \& Bakker, 2002). Riset ini sendiri akan menelaah lebih jauh mengenai pengaruh karakteristik pekerjaan dan efikasi diri terhadap keterikatan kerja serta implikasinya terhadap kepuasan kerja pegawai di Kecamatan Samarinda Ilir.

Tujuan dari riset ini adalah untuk mengekplorasi dan mendapatkan gambaran, analisis serta bukti dari adanya pengaruh karakteristik pekerjaan dan efikasi diri terhadap keterikatan kerja serta implikasinya terhadap kepuasan kerja pegawai di Kecamatan Samarinda Ilir.

\section{Metode Penelitian}

Penelitian ini dilakukan dengan menggunakan penelitian kuantitatif dengan tipe penelitian eksplanatori atau penjelasan (Sugiyono, 2018). Populasi pada penelitian ini adalah seluruh Pegawai Negeri Sipil (PNS) di Kecamatan Samarinda Ilir sebanyak 60 orang, terdiri dari 20 orang PNS Kecamatan dan 40 orang PNS Kelurahan. Pengumpulan data menggunakan kuesioner elektronik melalui google form yang dibagikan secara personal kepada responden. Dalam penelitian ini, kuesioner terdiri dari item-item pengukuran variabel karakteristik pekerjaan (5 item), efikasi diri (3 item), keterikatan kerja (9 item) dan kepuasan kerja (4 item) yang disampaikan kepada PNS Kecamatan dan PNS Kelurahan di Kecamatan Samarinda Ilir. Skala pengukuran yang digunakan adalah skala likert. Format tanggapan adalah 5 poin, skala tipe likert menggunakan sangat setuju hingga sangat tidak setuju sebagai poin akhir (J. F. Et Al Hair, 2017).

Partial Least Square Structural Equation Modeling (PLS-SEM) digunakan untuk menganalisis data dalam penelitian ini. PLS dalam penelitian ini akan menganalisis konstruk yang dibentuk dengan indikator reflektif. Tujuan PLS adalah membantu peneliti untuk tujuan prediksi. Bentuk model formalnya menjelaskan variabel laten sebagai agregat linier dari indikator pembentuknya (Imam \& Latan, 2014). Tahapan analisis dengan PLS dilakukan melalui lima tahap dimana setiap tahap akan mempengaruhi tahap selanjutnya: (1) menyusun konseptualisasi model, (2) menentukan teknik analisis algoritma, (3) menentukan teknik resampling, (4) menggambar diagram jalur, dan (5) mengevaluasi model (Imam \& Latan, 2014). Dua langkah utama yang dilakukan dalam menganalisis hasil keluaran pada Smart PLS yaitu evaluasi model pengukuran dan evaluasi model struktural (Joseph F. Hair, Risher, Sarstedt, \& Ringle, 2019).

\section{Hasil dan Pembahasan}

\section{Pengujian Hipotesis Pengaruh Langsung dan Tidak Langsung}

Uji hipotesis dilakukan dengan membandingkan nilai $\mathrm{t}$-tabel dengan nilai $\mathrm{t}$-statistik yang diperoleh dari hasil pengujian bootstrapping. Hipotesis diterima apabila nilai t- 
statistik atau t-hitung $>\mathrm{t}$-tabel $(1,96)$ dengan $\alpha=0,05$ dan $\mathrm{p}$-value $<0,05$. Pengujian hipotesis pengaruh langsung antara variabel eksogen terhadap endogen dapat dilihat pada hasil pengujian PLS bootstrapping sebagaimana ditunjukkan pada gambar berikut:

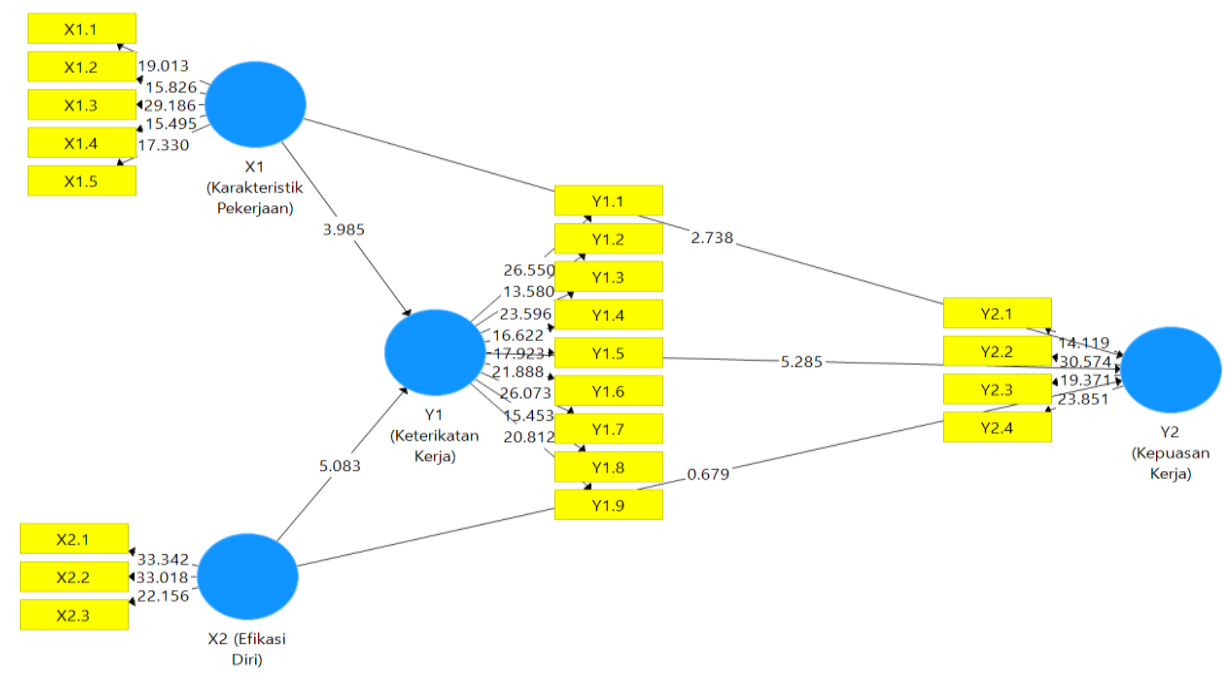

\section{Gambar 1 \\ Output PLS Bootstrapping}

Sumber Gambar: Diolah Peneliti, 2021

Adapun koefisien jalur dan pengujian hipotesis pengaruh langsung antara variabel eksogen dan endogen dapat dilihat pada tabel berikut.

Tabel 1

Koefisien Jalur dan Pengujian Hipotesis Langsung

\begin{tabular}{lllll}
\hline Variabel & Koefisien Jalur & T-Statistics & P-Values & Ket. \\
\hline Karakteristik Pekerjaan (X1) -> Keterikatan Kerja (Y1) & 0,409 & 3,985 & 0,000 & Signifikan \\
Efikasi Diri (X2) -> Keterikatan Kerja (Y1) & 0,421 & 5,083 & 0,000 & Signifikan \\
Karakteristik Pekerjaan (X1) -> Kepuasan Kerja (Y2) & 0,285 & 2,738 & 0,006 & Signifikan \\
Efikasi Diri (X2) -> Kepuasan Kerja (Y2) & 0,072 & 0,679 & 0,498 & Tidak \\
Keterikatan Kerja (Y1) -> Kepuasan Kerja (Y2) & 0,573 & 5,285 & 0,000 & Signifikan \\
\hline
\end{tabular}

Sumber: Hasil Olah Data (2021)

Sedangkan koefisien jalur dan pengujian hipotesis pengaruh tidak langsung antara variabel eksogen dan endogen dapat dilihat pada tabel berikut.

Tabel 2

Koefisien Jalur dan Pengujian Hipotesis Tidak Langsung

\begin{tabular}{|c|c|c|c|c|c|}
\hline \multicolumn{3}{|l|}{ Variabel } & \multirow{2}{*}{$\begin{array}{l}\text { Koefisien } \\
\text { Jalur }\end{array}$} & \multirow{2}{*}{ T Statistics } & \multirow{2}{*}{$\begin{array}{l}P \\
\text { Values }\end{array}$} \\
\hline Eksogen & Mediasi & Endogen & & & \\
\hline $\begin{array}{l}\text { Karakteristik Pekerjaan } \\
\text { (X1) }\end{array}$ & $\begin{array}{l}\text { Keterikatan } \\
\text { Kerja (Y1) }\end{array}$ & $\begin{array}{l}\text { Kepuasan } \\
\text { Kerja (Y2) }\end{array}$ & 0,234 & 2,892 & 0,004 \\
\hline Efikasi Diri (X2) & $\begin{array}{l}\text { Keterikatan } \\
\text { Kerja (Y1) }\end{array}$ & $\begin{array}{l}\text { Kepuasan } \\
\text { Kerja (Y2) }\end{array}$ & 0,242 & 3,338 & 0,001 \\
\hline
\end{tabular}

Sumber: Hasil Olah Data (2021) 
Hasil pengujian hipotesis selanjutnya dijelaskan sebagai berikut. Hasil uji hipotesis pada tabel 1 menunjukkan pengaruh karakteristik pekerjaan (X1) terhadap keterikatan kerja (Y1) melalui nilai koefisien jalur sebesar 0,409, t-statistik sebesar 3,985 dan p-value sebesar 0,000. Nilai tersebut memenuhi syarat untuk penerimaan H1. Nilai koefisien jalur 0,409 menunjukkan bahwa arah hubungan antara variabel $\mathrm{X} 1$ dan $\mathrm{Y} 1$ adalah positif, sedangkan nilai $\mathrm{t}$-statistik lebih besar dari $\mathrm{t}$-tabel $(1,96)$ dan nilai p-value lebih kecil dari 0,05. Berdasarkan hasil tersebut dapat disimpulkan bahwa karakteristik pekerjaan berpengaruh positif dan signifikan terhadap keterikatan kerja, maka hipotesis 1 diterima.

Hasil uji hipotesis pada tabel 1 menunjukkan pengaruh efikasi diri (X2) terhadap keterikatan kerja (Y1) melalui nilai koefisien jalur sebesar 0,421, t-statistik sebesar 5,083 dan $\mathrm{p}$-value sebesar 0,000 . Nilai tersebut memenuhi syarat untuk penerimaan H2. Nilai koefisien jalur 0,421 menunjukkan bahwa arah hubungan antara variabel $\mathrm{X} 2$ dan $\mathrm{Y} 1$ adalah positif, sedangkan nilai $\mathrm{t}$-statistik lebih besar dari $\mathrm{t}$-tabel $(1,96)$ dan nilai $\mathrm{p}$-value lebih kecil dari 0,05 . Berdasarkan hasil tersebut dapat disimpulkan bahwa efikasi diri berpengaruh positif dan signifikan terhadap keterikatan kerja, maka hipotesis 2 diterima.

Hasil uji hipotesis pada tabel 1 menunjukkan pengaruh karakteristik pekerjaan (X1) terhadap kepuasan kerja (Y2) melalui nilai koefisien jalur sebesar 0,285, t-statistik sebesar 2,738 dan p-value sebesar 0,006. Nilai tersebut memenuhi syarat untuk penerimaan H3. Nilai koefisien jalur 0,285 menunjukkan bahwa arah hubungan antara variabel X1 dan Y2 adalah positif, sedangkan nilai t-statistik lebih besar dari ttabel $(1,96)$ dan nilai $p$-value lebih kecil dari 0,05 . Berdasarkan hasil tersebut dapat disimpulkan bahwa karakteristik pekerjaan memiliki pengaruh yang positif dan signifikan terhadap kepuasan kerja, maka hipotesis 3 diterima.

Hasil uji hipotesis pada tabel 1 menunjukkan pengaruh efikasi diri (X2) terhadap kepuasan kerja (Y2) melalui nilai koefisien jalur sebesar 0,072, t-statistik sebesar 0,679 dan p-value sebesar 0,498. Nilai tersebut tidak memenuhi syarat untuk penerimaan $\mathrm{H} 4$. Nilai koefisien jalur 0,072 menunjukkan bahwa arah hubungan antara variabel X2 dan $\mathrm{Y} 2$ adalah positif, sedangkan nilai $\mathrm{t}_{\text {-statistik }}$ lebih kecil dari $\mathrm{t}_{\text {-tabel }}(1,96)$ dan nilai $\mathrm{p}$ value lebih besar dari 0,05. Berdasarkan hasil tersebut dapat disimpulkan bahwa efikasi diri berpengaruh positif namun tidak signifikan terhadap kepuasan kerja, maka hipotesis 4 ditolak.

Hasil uji hipotesis pada tabel 1 menunjukkan pengaruh keterikatan kerja (Y1) terhadap kepuasan kerja (Y2) melalui nilai koefisien jalur sebesar 0,573, t-statistik sebesar 5,285 dan $\mathrm{p}$-value sebesar 0,000. Nilai tersebut memenuhi syarat untuk penerimaan H5. Nilai koefisien jalur 0,573 menunjukkan bahwa arah hubungan antara variabel Y1 dan Y2 adalah positif, sedangkan nilai t-statistik lebih besar dari ttabel $(1,96)$ dan nilai $\mathrm{p}$-value lebih kecil dari 0,05 . Berdasarkan hasil tersebut dapat disimpulkan bahwa keterikatan kerja memiliki pengaruh positif dan signifikan terhadap kepuasan kerja, maka hipotesis 5 diterima. 
Hasil uji hipotesis pada tabel 2 menunjukkan bahwa keterikatan kerja mampu memberikan efek mediasi (partial mediation) dalam hubungan pengaruh antara karakteristik pekerjaan terhadap kepuasan kerja. Hal tersebut dibuktikan dengan nilai p-value sebesar 0,004 atau lebih kecil dari 0,05 dan t-statistik sebesar 2,892 atau lebih besar dari t-tabel $(1,96)$. Berdasarkan hasil tersebut dapat disimpulkan bahwa variabel keterikatan kerja memberikan pengaruh yang positif dan signifikan terhadap hubungan antara variabel karakteristik pekerjaan dengan kepuasan kerja, maka H6 diterima.

Hasil uji hipotesis pada tabel 2 menunjukkan bahwa keterikatan kerja mampu memberikan efek mediasi (full mediation) dalam hubungan pengaruh antara efikasi diri terhadap kepuasan kerja. Hal tersebut dibuktikan dengan nilai p-value sebesar 0,001 atau lebih kecil dari 0,05 dan t-statistik sebesar 3,338 atau lebih besar dari $\mathrm{t}$-tabel $(1,96)$. Berdasarkan hasil tersebut dapat disimpulkan bahwa variabel keterikatan kerja memberikan pengaruh yang positif dan signifikan terhadap hubungan antara variabel efikasi diri dengan kepuasan kerja, maka $\mathrm{H} 7$ diterima.

\section{Pengaruh Karakteristik Pekerjaan terhadap Keterikatan Kerja}

Berdasarkan hasil analisis dan pengujian hipotesis membuktikan bahwa karakteristik pekerjaan memiliki pengaruh positif dan signifikan terhadap keterikatan kerja pegawai, yang berarti bahwa semakin tinggi tingkat karakteristik pekerjaan, maka akan berimplikasi pada semakin tingginya keterikatan kerja pegawai di Kecamatan Samarinda Ilir. Hal ini menunjukkan bahwa tingginya tuntutan keragaman keterampilan (skill variety), memiliki identitas tugas yang jelas (task identity), signifikansi tugas yang baik (task significance), otonomi tugas yang tinggi (autonomy), serta umpan balik yang mudah diperoleh (feedback) akan menyebabkan tingginya keterikatan kerja pegawai di Kecamatan Samarinda Ilir.

Ketika pegawai Kecamatan Samarinda Ilir merasa bahwa pekerjaannya merupakan pekerjaan yang bermakna, mengetahui sejauh mana baik atau buruk pekerjaan yang dilakukannya, dilibatkan dalam setiap aktivitas pekerjaan, diberikan pekerjaan-pekerjaan yang membutuhkan berbagai keterampilan, dan diberikan kesempatan untuk berpartisipasi dalam menentukan keputusan, maka akan menimbulkan rasa terikat pegawai terhadap pekerjaannya. Keterikatan pegawai dengan pekerjaannya disebabkan oleh pekerjaan mereka yang memiliki arti penting untuk kepentingan umum dan kesesuaian nilai pegawai dengan nilai yang ditetapkan oleh organisasi (Akingbola \& van den Berg, 2019). Temuan ini sejalan dengan riset sebelumnya yang menyatakan bahwa karakteristik pekerjaan menjadi prediktor yang kuat dari munculnya keterikatan kerja (Kahn, 1990); (Prameswari, 2019); (Sulin, 2018); (Sulistyo \& Suhartini, 2019).

Hasil analisis menunjukkan bahwa indikator signifikansi tugas merupakan faktor utama dalam meningkatkan keterikatan kerja pegawai di Kecamatan Samarinda Ilir. Pegawai merasa bahwa pekerjaannya merupakan pekerjaan yang bermakna dan penting bagi orang lain. Hal ini terkait dengan tugas dan fungsi utama Kecamatan dalam memberikan pelayanan kepada masyarakat, apabila tidak dilaksanakan dengan 
baik maka akan berdampak pada terhambatnya tugas-tugas pegawai yang lain serta kepentingan masyarakat itu sendiri sehingga pelayanan yang diberikan kepada masyarakat tidak berjalan optimal. Indikator karakteristik pekerjaan selanjutnya yang turut mempengaruhi keterikatan kerja pegawai adalah variasi keterampilan, yang artinya pemanfaatan keragaman keterampilan oleh pegawai dalam melakukan pekerjaannya juga akan mempengaruhi keterikatan kerja pegawai. Ketika tingkat variasi pekerjaan tinggi, dimana hampir setiap hari dalam melaksanakan pekerjaan menggunakan berbagai cara yang berbeda, maka pegawai jarang merasa monoton terhadap pekerjaannya. Indikator yang juga mempengaruhi keterikatan kerja pegawai di Kecamatan Samarinda Ilir adalah umpan balik dan identitas tugas, yaitu pegawai memiliki informasi mengenai sistem kerja dan hasil kinerja yang dilakukannya serta dapat menunjukkan hasil dari pekerjaannya.

Indikator yang memiliki pengaruh terendah terhadap keterikatan kerja pegawai adalah otonomi, yaitu pegawai diberikan kebebasan dalam menentukan prosedur dan jadwal pelaksanaan kerja. Hal ini dikarenakan Kecamatan sebagai eksekutor kebijakan daerah sudah memiliki Standar Operasional Prosedur (SOP) dan target yang harus dicapai dalam pelaksanaan tugas, namun seringkali kondisi dan situasi di lapangan yang tidak menentu membutuhkan kreativitas dan inovasi pegawai untuk mempermudah pelaksanaan pekerjaan. Oleh karenanya organisasi maupun pimpinan diharapkan memberikan keleluasaan kepada pegawai untuk menentukan prosedur yang digunakan dalam melaksanakan pekerjaan. Apabila pegawai diberikan kewenangan untuk menentukan prosedur dan jadwal kerja, maka pegawai akan melihat hasil pekerjaan sebagai usaha sendiri, sehingga pegawai dapat lebih bertanggung jawab dan terikat terhadap pekerjaannya.

\section{Pengaruh Efikasi Diri terhadap Keterikatan Kerja}

Berdasarkan hasil analisis dan pengujian hipotesis menunjukkan bahwa efikasi diri memiliki pengaruh positif dan signifikan terhadap keterikatan kerja pegawai, yang berarti bahwa semakin tinggi efikasi diri yang dimiliki seorang pegawai, maka akan berimplikasi pada semakin terikatnya pegawai tersebut terhadap pekerjaannya. Penelitian ini membuktikan bahwa tingginya kepercayaan diri pegawai terhadap kompetensi yang dimiliki dalam menyelesaikan pekerjaan, kepercayaan diri dapat menyelesaikan pekerjaan meskipun terdapat banyak hambatan dan kesulitan, serta penilaian orang lain terhadap kemampuan dan keterampilan yang dimiliki pegawai akan menyebabkan tingginya keterikatan kerja pada diri pegawai. Semakin tinggi tingkat efikasi diri individu, semakin tinggi tingkat kepercayaan diri individu tersebut akan kemampuannya untuk berhasil. Individu dengan efikasi diri rendah cenderung tidak akan berusaha keras atau menyerah, sedangkan individu dengan efikasi diri tinggi cenderung akan berusaha keras menghadapi tantangan. Efikasi diri dapat menciptakan spiral positif dimana individu yang memiliki efikasi diri yang tinggi dapat menjadi lebih terikat pada pekerjaannya dan meningkatkan kinerja individu tersebut (Robbins S.P., Judge T.A., 2015). 
Hasil ini kemudian sejalan dengan riset terdahulu bahwa efikasi diri memiliki hubungan yang positif dan signifikan terhadap keseluruhan dimensi keterikatan kerja dan efikasi diri penting ditingkatkan di tempat kerja untuk memotivasi pegawai dalam rangka menghadapi tuntutan dan tantangan pekerjaan (Yu et al., 2020); (Al-Hamdan \& Bani Issa, 2021). Pegawai dengan tingkat efikasi diri yang tinggi akan lebih percaya diri dalam mengerjakan dan menyelesaikan tugasnya, lebih aktif, dan mampu menangani tantangan ataupun kesulitan dalam pekerjaannya. Pegawai dengan efikasi diri yang tinggi akan mampu bertahan meskipun tantangan terus berdatangan pada saat menyelesaikan pekerjaan (Mejia et al., 2021).

\section{Pengaruh Karakteristik Pekerjaan terhadap Kepuasan Kerja}

Berdasarkan hasil analisis dan pengujian hipotesis membuktikan bahwa karakteristik pekerjaan memiliki pengaruh positif dan signifikan terhadap kepuasan kerja pegawai di Kecamatan Samarinda Ilir, yang berarti bahwa semakin tinggi tingkat karakteristik pekerjaan, maka akan berimplikasi pada semakin tingginya kepuasan kerja pegawai. Hal ini menunjukkan bahwa tingginya tuntutan keragaman keterampilan (skill variety), memiliki identitas tugas yang jelas (task identity), signifikansi tugas yang baik (task significance), otonomi tugas yang tinggi (autonomy), serta umpan balik yang mudah diperoleh (feedback) akan menyebabkan tingginya kepuasan kerja pegawai di Kecamatan Samarinda Ilir.

Desain pekerjaan yang mencakup lima dimensi inti atau model karakteristik pekerjaan dapat memunculkan rasa kebermaknaan akan pekerjaan bagi pegawai, membangkitkan rasa tanggung jawab pegawai atas kinerjanya, dan menunjukkan seberapa efektif mereka bekerja. Konsep model karakteristik pekerjaan tidak hanya mengarah pada kepuasan kerja dan komitmen organisasi, tetapi juga memotivasi pegawai (Robbins S.P., Judge T.A., 2015).

Temuan riset ini memperkuat penelitian sebelumnya yang menyatakan bahwa terdapat pengaruh yang positif dan signifikan antara karakteristik pekerjaan terhadap kepuasan kerja (Rai \& Maheshwari, 2020). Model karakteristik pekerjaan yang terdiri dari keberagaman kemampuan, identitas tugas, signifikansi tugas, otonomi dan umpan balik berpengaruh signifikan terhadap kepuasan kerja seseorang (Joseph, Jadhav, \& Vispute, 2021). Individu yang diberikan tanggung jawab lebih mengenai penyelesaian tugas atau pekerjaan, maka individu akan merasa puas terhadap pekerjaannya. Ketika suatu pekerjaan mengharuskan individu untuk menggunakan berbagai keterampilan dalam menyelesaikan pekerjaan, maka individu tersebut akan semakin tertarik dan puas dengan pekerjaannya.

\section{Pengaruh Efikasi Diri terhadap Kepuasan Kerja}

Berdasarkan hasil analisis dan pengujian hipotesis menunjukkan bahwa efikasi diri memiliki pengaruh positif yang tidak signifikan terhadap kepuasan kerja pegawai di Kecamatan Samarinda Ilir, artinya apabila efikasi diri mengalami peningkatan, maka kepuasan kerja pegawai di Kecamatan Ilir juga akan mengalami peningkatan, akan tetapi peningkatan efikasi diri belum mampu mendorong peningkatan kepuasan kerja pegawai secara nyata dikarenakan mempunyai nilai signifikansi yang tidak 
signifikan. Dapat disimpulkan secara nyata efikasi diri belum mampu memberikan efek atau dampak yang kuat terhadap kepuasan kerja pegawai di Kecamatan Samarinda Ilir. Hasil tidak signifikan pada penelitian ini disebabkan oleh kurangnya dukungan dari atasan dan rekan kerja kepada pegawai sehingga pegawai tidak memiliki kepercayaan diri untuk menyelesaikan pekerjaan dan mengatasi persoalan dalam pekerjaannya. Pada akhirnya menyebabkan pegawai merasa tidak puas dengan pekerjaannya.

Untuk lebih meningkatkan rasa percaya diri pegawai di Kecamatan Samarinda Ilir, organisasi harus membentuk lingkungan kerja yang supportif, dalam artian atasan dan rekan kerja diharapkan dapat memberikan dukungan positif kepada pegawai dan senantiasa memberikan pujian dan kalimat yang supportif. Ketika melihat pegawai sedang mengalami kesulitan dalam melaksanakan suatu tugas, maka atasan diharapkan dapat memberikan contoh dan mendampingi pegawai, dan rekan kerja dapat memberikan bantuan serta dukungan lisan yang positif agar pegawai dapat merasa lebih percaya diri untuk menghadapi kesulitan dan dapat menyelesaikan pekerjaannya. Dukungan lisan yang positif dari orang lain sangat diperlukan agar pegawai dapat merasa lebih percaya diri untuk menghadapi kesulitan dan dapat menyelesaikan pekerjaannya.

Temuan ini sejalan dengan riset terdahulu yang menyatakan bahwa tidak terdapat hubungan yang signifikan antara kepuasan kerja dengan efikasi diri (Kuru \& Katsaras, 2016); (Chegini et al., 2019). Namun temuan ini berbeda dengan temuan riset lain yang mengungkapkan bahwa efikasi diri memiliki pengaruh positif dan signifikan terhadap kepuasan kerja dimana pegawai yang memiliki efikasi diri yang tinggi akan memiliki pengalaman dan kemampuan yang superior, dan faktor-faktor tersebut dapat meningkatkan kepuasan kerja pegawai (Mokhtar et al., 2021). Efikasi diri tidak hanya berpengaruh terhadap keterikatan kerja, efikasi diri juga memiliki pengaruh signifikan terhadap kepuasan kerja dimana ketika seseorang memiliki efikasi diri yang tinggi, maka ia lebih efektif dalam menangani kesulitan, mampu bertahan dalam menghadapi kegagalan dan ia lebih memungkinkan untuk mencapai hasil pekerjaan yang dihargai sesuai dengan standar pribadinya (Chan, Ho, Ip, \& Wong, 2020).

\section{Pengaruh Keterikatan Kerja terhadap Kepuasan Kerja}

Berdasarkan hasil analisis dan pengujian hipotesis menunjukkan bahwa keterikatan kerja memiliki pengaruh positif yang signifikan terhadap kepuasan kerja, artinya semakin tinggi keterikatan kerja pegawai akan berimplikasi pada semakin meningkatnya kepuasan kerja. Pegawai yang gigih dalam menghadapi kesulitan, merasa tertantang dalam menyelesaikan tugas-tugas yang diberikan, memiliki energi dan ketahanan mental saat bekerja, serta memiliki minat yang mendalam terhadap pekerjaan, hal tersebut merupakan sebab dari munculnya kepuasan kerja. Keterikatan kerja merupakan sejauh mana seseorang merasa terikat, puas, dan antusias terhadap pekerjaannya (Robbins S.P., Judge T.A., 2015). Keterikatan kerja merupakan payung yang mencakup berbagai konsekuensi apabila hal tersebut terbangun dalam suatu 
organisasi, seperti komitmen organisasi, kepuasan kerja, dan variabel lain yang dapat mendukung organisasi untuk mencapai tujuannya.

Temuan riset ini sejalan dengan riset terdahulu dimana keterikatan kerja memiliki pengaruh yang positif dan signifikan terhadap munculnya kepuasan kerja, dengan semakin terikatnya pegawai terhadap pekerjaannya, maka kepuasan kerja pegawai juga akan semakin meningkat (Orgambídez-Ramos \& de Almeida, 2017); (Sulistyo \& Suhartini, 2019). Untuk meningkatkan keterikatan kerja pegawai di Kecamatan Samarinda Ilir, pegawai diharapkan dapat meningkatkan konsentrasi dan fokus saat bekerja serta lebih bersungguh-sungguh dalam melakukan pekerjaan. Organisasi dan pimpinan diharapkan dapat melakukan evaluasi terhadap kinerja pegawai secara rutin dan memberikan reward atau penghargaan bagi pegawai yang berprestasi, hal ini dilakukan untuk mendorong semangat bagi pegawai untuk meningkatkan disiplin dan tanggung jawab untuk terus meningkatkan kinerjanya, sehingga pegawai akan merasa terikat dengan pekerjaannya yang akan berdampak pada kepuasan kerja.

\section{Pengaruh Karakteristik Pekerjaan terhadap Kepuasan Kerja melalui Keterikatan Kerja}

Berdasarkan hasil analisis dan pengujian hipotesis menunjukkan bahwa karakteristik pekerjaan berpengaruh positif dan signifikan terhadap kepuasan kerja melalui keterikatan kerja, artinya keterikatan kerja mampu memediasi hubungan antara karakteristik pekerjaan terhadap kepuasan kerja pegawai di Kecamatan Samarinda Ilir. Mediasi dalam hubungan ini termasuk kedalam kategori partial mediation. Secara positif dan signifikan keterikatan kerja mampu memberikan efek mediasi pada pengaruh antara karakteristik pekerjaan terhadap kepuasan kerja pegawai, yang berarti bahwa untuk meningkatkan kepuasan kerja pegawai dengan variabel karakteristik pekerjaan, akan lebih baik apabila turut memperhatikan tingkat keterikatan kerja pegawai, karena karakteristik pekerjaan yang menimbulkan rasa keterikatan kerja yang kuat akan berakibat pada peningkatan kepuasan kerja pegawai.

Hasil ini menunjukkan bahwa tingginya tuntutan keragaman keterampilan, memiliki identitas tugas yang jelas, signifikansi tugas yang baik, otonomi tugas yang tinggi, serta umpan balik yang mudah diperoleh akan menyebabkan tingginya keterikatan kerja pada diri pegawai, selanjutnya tingginya keterikatan kerja pegawai akan menyebabkan peningkatan pada kepuasan kerja. Temuan ini kemudian sejalan dengan temuan riset sebelumnya dimana karakteristik pekerjaan memiliki pengaruh positif dan signifikan terhadap kepuasan kerja yang dimediasi oleh keterikatan kerja (Rai \& Maheshwari, 2020).

\section{Pengaruh Efikasi Diri terhadap Kepuasan Kerja melalui Keterikatan Kerja}

Berdasarkan hasil analisis dan pengujian hipotesis menunjukkan bahwa efikasi diri berpengaruh positif dan signifikan terhadap kepuasan kerja melalui keterikatan kerja, artinya keterikatan kerja mampu memediasi hubungan antara efikasi diri dengan kepuasan kerja pegawai di Kecamatan Samarinda Ilir. Mediasi dalam 
hubungan ini termasuk kedalam kategori full mediation. Secara positif dan signifikan keterikatan kerja mampu memberikan efek mediasi pada pengaruh antara efikasi diri dengan kepuasan kerja pegawai, yang berarti bahwa untuk meningkatkan kepuasan kerja dengan variabel efikasi diri, perlu memperhatikan tingkat keterikatan kerja pegawai, karena efikasi diri yang menimbulkan rasa keterikatan kerja yang kuat akan berimplikasi pada peningkatan kepuasan kerja pegawai.

Hasil ini menunjukkan bahwa tingginya kepercayaan diri pegawai terhadap kompetensi yang dimiliki dalam menyelesaikan pekerjaan, kepercayaan diri dapat menyelesaikan pekerjaan meskipun terdapat banyak hambatan dan kesulitan, serta penilaian orang lain terhadap kemampuan dan keterampilan yang dimiliki pegawai akan menyebabkan tingginya keterikatan kerja pada diri pegawai, selanjutnya tingginya keterikatan kerja pegawai akan menyebabkan peningkatan pada kepuasan kerja. Temuan ini sejalan dengan riset terdahulu dimana terdapat pengaruh mediasi keterikatan kerja diantara hubungan efikasi diri dengan kepuasan kerja. Keterikatan kerja berperan menjelaskan hubungan antara efikasi diri dengan kepuasan kerja. Karyawan yang memiliki tingkat efikasi diri yang tinggi akan lebih terikat dan lebih puas terhadap pekerjaannya (Chan et al., 2020).

\section{Kesimpulan}

Karakteristik pekerjaan dan efikasi diri memiliki pengaruh positif dan signifikan terhadap keterikatan kerja pegawai Kecamatan Samarinda Ilir, hal ini berarti semakin tinggi tingkat karakteristik pekerjaan dan efikasi diri, maka semakin tinggi pula rasa keterikatan kerja pegawai terhadap pekerjaannya. Untuk meningkatkan keterikatan kerja pegawai melalui variabel karakteristik pekerjaan, pimpinan dan organisasi Kecamatan Samarinda Ilir diharapkan memberikan kesempatan kepada pegawai untuk menentukan prosedur dan jadwal kerja yang digunakan dalam melaksanakan pekerjaan. Sementara untuk meningkatkan keterikatan kerja pegawai melalui variabel efikasi diri, pegawai diharapkan mampu menjaga rasa yakin terhadap kompetensi atau kemampuan pada diri sendiri dan percaya mampu menyelesaikan pekerjaan meskipun terdapat banyak hambatan dan kesulitan.

Karakteristik pekerjaan memiliki pengaruh positif dan signifikan terhadap kepuasan kerja pegawai Kecamatan Samarinda Ilir, hal ini berarti semakin tinggi tingkat karakteristik pekerjaan, maka semakin tinggi pula kepuasan kerja pegawai. Untuk meningkatkan kepuasan kerja pegawai melalui variabel karakteristik pekerjaan, pegawai perlu diberikan pekerjaan yang menantang, pekerjaan yang teridentifikasi dari awal hingga akhir, pekerjaan yang berdampak besar terhadap organisasi ataupun lingkungan eksternal, diberi otonomi dalam menyelesaikan pekerjaan, dan diberi informasi yang jelas mengenai hasil kerja atau kinerjanya, sehingga mereka terpacu dan termotivasi untuk bekerja lebih keras, ketika mereka puas terhadap pekerjaannya maka dalam melaksanakan pekerjaan selanjutnya mereka akan memberikan kinerja yang lebih baik. 
Efikasi diri berpengaruh positif yang tidak signifikan terhadap kepuasan kerja pegawai Kecamatan Samarinda Ilir, artinya secara nyata efikasi diri belum mampu memberikan efek atau dampak yang kuat terhadap kepuasan kerja pegawai di Kecamatan Samarinda Ilir. Untuk meningkatkan kepuasan kerja pegawai melalui variabel efikasi diri, organisasi harus membentuk lingkungan kerja yang supportif. Ketika melihat pegawai sedang mengalami kesulitan dalam melaksanakan suatu tugas, maka atasan diharapkan dapat memberikan contoh dan mendampingi pegawai, dan rekan kerja dapat memberikan bantuan serta dukungan lisan yang positif agar pegawai dapat merasa lebih percaya diri untuk menghadapi kesulitan dan dapat menyelesaikan pekerjaannya.

Keterikatan kerja berpengaruh positif dan signifikan terhadap kepuasan kerja pegawai Kecamatan Samarinda Ilir, hal ini berarti semakin tinggi tingkat keterikatan kerja pegawai, maka semakin tinggi pula kepuasan kerja pegawai. Untuk meningkatkan kepuasan kerja melalui variabel keterikatan kerja, pegawai diharapkan dapat meningkatkan konsentrasi dan fokus saat bekerja serta lebih bersungguh-sungguh dalam melakukan pekerjaan. Evaluasi terhadap kinerja pegawai perlu dilakukan secara rutin oleh pimpinan untuk meningkatkan disiplin dan tanggung jawab pegawai. Pemberian reward bagi pegawai yang berprestasi perlu dilakukan untuk mendorong semangat pegawai dalam meningkatkan kinerjanya.

Karakteristik pekerjaan berpengaruh positif dan signifikan terhadap kepuasan kerja melalui keterikatan kerja, yang berarti bahwa keterikatan kerja mampu memediasi hubungan antara karakteristik pekerjaan terhadap kepuasan kerja pegawai di Kecamatan Samarinda Ilir. Sementara efikasi diri juga berpengaruh positif dan signifikan terhadap kepuasan kerja melalui keterikatan kerja, yang berarti bahwa keterikatan kerja mampu memediasi hubungan antara efikasi diri terhadap kepuasan kerja pegawai di Kecamatan Samarinda Ilir. Penelitian selanjutnya diharapkan dapat menjelaskan lebih dalam mengenai keterikatan kerja dan dapat menjelaskan faktor-faktor yang memiliki pengaruh terhadap keterikatan kerja yang tidak terdapat pada penelitian ini, seperti variabel kecerdasan emosional, kepemimpinan, dan kondisi kerja. 
Fiona Citrayani, Tetra Hidayati, Saida Zainurossalamia

\section{BIBLIOGRAFI}

Akingbola, Kunle, \& van den Berg, Herman A. (2019). Antecedents, consequences, and context of employee engagement in nonprofit organizations. Review of Public Personnel Administration, 39(1), 46-74. Google Scholar

Al-Hamdan, Zaid, \& Bani Issa, Haneen. (2021). The role of organizational support and self-efficacy on work engagement among registered nurses in Jordan: A descriptive study. Journal of Nursing Management. Google Scholar

Chan, Edmund S. S., Ho, Sammy K., Ip, Flora F. L., \& Wong, Marina W. Y. (2020). Self-efficacy, work engagement, and job satisfaction among teaching assistants in hong kong's inclusive education. SAGE Open, 10(3), 2158244020941008. Google Scholar

Chegini, Zahra, Janati, Ali, Asghari-Jafarabadi, Mohammad, \& Khosravizadeh, Omid. (2019). Organizational commitment, job satisfaction, organizational justice and self-efficacy among nurses. Nursing Practice Today, 6(2), 86-93. Google Scholar

Colquitt, Jason, Lepine, J. A., \& Wesson, M. J. (2014). Organizational Behavior: Improving Performance and Commitment in the Workplace (4e). New York, NY, USA: McGraw-Hill. Google Scholar

Diamantidis, Anastasios D., \& Chatzoglou, Prodromos. (2019). Factors affecting employee performance: an empirical approach. International Journal of Productivity and Performance Management, 68(1), 171-193. Google Scholar

Fauzan, Rizki. (2020). Mediating Effect Of Job Satisfaction And Organizational Commitment In Influence Of Job Characteristics Towards Performance. Journal of Critical Reviews, 7(13), 744-754. Google Scholar

Hackman, J. Richard, \& Oldham, Greg R. (1976). Motivation through the design of work: test of a theory. Organizational Behavior and Human Performance, 16(2), 250-279. Google Scholar

Hair, J. F. Et Al. (2017). A Primer On Partial Least Squares Structural Equation Modeling (Pls-Sem) (2nd Edn). Usa: Sage Publications, Inc. Google Scholar

Hair, Joseph F., Risher, Jeffrey J., Sarstedt, Marko, \& Ringle, Christian M. (2019). When to use and how to report the results of PLS-SEM. European Business Review, 31(1), 2-24. Google Scholar

Imam, Ghozali, \& Latan, Hengki. (2014). Partial Least Square (PLS) konsep teknik dan aplikasi. Semarang: Universitas Diponegoro Semarang. Google Scholar

Joseph, Shaji, Jadhav, Anil, \& Vispute, Bhamini. (2021). Role of ethical organisational culture on employee job satisfaction: an empirical study. International Journal of Business Governance and Ethics, 1(1), 1.

Kahn, William A. (1990). Psychological conditions of personal engagement and 
disengagement at work. Academy of Management Journal, 33(4), 692-724. Google Scholar

Kreitner, R. And Kinicki, A. (2013). Organizational Behaviour. 10th Edn. New York: Mcgraw-Hill Companies, Inc.

Kuru, Nilgün, \& Katsaras, Thodoris. (2016). Job satisfaction and perceived self-efficacy among greek nurses. Google Scholar

Lightsey, Richard. (1999). Albert Bandura and the exercise of self-efficacy. Journal of Cognitive Psychotherapy, 13(2), 158. Google Scholar

Mappamiring, Mappamiring, AKOB, Muhammad, \& Putra, Aditya Halim Perdana Kusuma. (2020). What Millennial Workers Want? Turnover or Intention to Stay in Company. The Journal of Asian Finance, Economics, and Business, 7(5), 237-248. Google Scholar

Mejia, Grethel L., Dajac, Shari, Dotig, Maureen G., Romantico, Abby Gayle Q., Sanmocte, Joshua G., \& Castillo-arenillo, Alethea Patricia Del. (2021). The Relationship Between Self-Efficacy And Work Engagement Among Teachers Psychology Student, Colegio de San Juan de Letran-Manila. 8(1), 29-33. Google Scholar

Mokhtar, Aida, Maouloud, Vatimetou Mokhtar, Omowunmi, Asafa Kafayat, \& Nordin, Mohamad Sahari bin. (2021). Teachers' commitment, self-efficacy and job satisfaction as communicated by trained teachers. Management in Education, 08920206211019400. Google Scholar

Narcisse, Sharon, \& Harcourt, Mark. (2008). Employee fairness perceptions of performance appraisal: A Saint Lucian case study. The International Journal of Human Resource Management, 19(6), 1152-1169. Google Scholar

Orgambídez-Ramos, Alejandro, \& de Almeida, Helena. (2017). Work engagement, social support, and job satisfaction in Portuguese nursing staff: A winning combination. Applied Nursing Research, 36, 37-41. Google Scholar

Prameswari, G. A. (2019). the Effects of Job Characteristics on Work Engagement. Russian Journal of Agricultural and Socio-Economic Sciences, 85(1), 475-479. Google Scholar

Rai, Alka, \& Maheshwari, Sunil. (2020). Exploring the mediating role of work engagement between the linkages of job characteristics with organizational engagement and job satisfaction. Management Research Review. Google Scholar

Robbins, S. P. And Judge, T. A. (2015). Organizational Behavior (16th Editi). Usa: Pearson Education Inc. Google Scholar

Robbins S.P., Judge T.A. (2015). Perilaku Organisasi. Edisi 16. Jakarta: Salemba Empat. Google Scholar 
Fiona Citrayani, Tetra Hidayati, Saida Zainurossalamia

Saks, Alan M. (2019). Antecedents and consequences of employee engagement revisited. Journal of Organizational Effectiveness: People and Performance. Google Scholar

Saragih, Susanti, \& Margaretha, Meily. (2013). Anteseden dan konsekuensi employee engagement: studi pada industri perbankan. Seminar Nasional \& Call for Paper: Perkembangan Kewirausahaan Dan Tantangannya Dalam Menghadapi Perekonomian Indonesia Di Masa Yang Akan Datang, 19-20. Google Scholar

Schaufeli, Wilmar B., Salanova, Marisa, González-Romá, Vicente, \& Bakker, Arnold B. (2002). The measurement of engagement and burnout: A two sample confirmatory factor analytic approach. Journal of Happiness Studies, 3(1), 71-92. Google Scholar

Smith, Patricia Cain. (1969). The measurement of satisfaction in work and retirement: A strategy for the study of attitudes. Google Scholar

Sugiyono. (2018). Metode Penelitian Kuantitatif Kulitatif dan R\&D. Bandung: Alfabeta.

Sulin, Sulin. (2018). Efek mediasi work engagement dalam pengaruh job characteristic dan perceived organizational support terhadap employee performance di bidang teknologi informasi. Universitas Tarumanagara. Google Scholar

Sulistyo, Adhe Rachman, \& Suhartini, Suhartini. (2019). The Role of Work Engagement in Moderating the Impact of Job Characteristics, Perceived Organizational Support, and Self-Efficacy on Job Satisfaction. Integrated Journal of Business and Economics, 3(1), 15. Google Scholar

Turner, Mark, \& Hulme, David. (1997). Governance, administration and development: Making the state work. Springer. Google Scholar

Yu, Jongsik, Ariza-Montes, Antonio, Giorgi, Gabriele, Lee, Aejoo, \& Han, Heesup. (2020). Sustainable relationship development between hotel company and its employees: Linking job embeddedness, job satisfaction, self-efficacy, job performance, work engagement, and turnover. Sustainability, 12(17), 7168. Google Scholar

\section{Copyright holder:}

Fiona Citrayani, Tetra Hidayati, Saida Zainurossalamia (2022)

First publication right:

Syntax Literate: Jurnal Ilmiah Indonesia

This article is licensed under: 